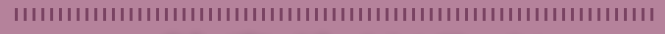

診療ガイドライン

at a glance

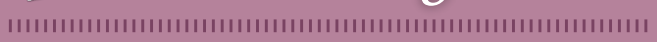

\section{慢性便秘症診療 ガイドライン2017}

\section{Key words}

慢性便秘症，定義，疫学，診断，治療

〔日内会誌 109：254～259，2020〕

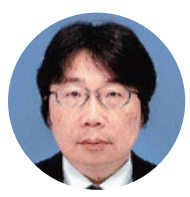

\section{眞部 紀明1)，春間 賢2)}

1）川崎医科大学検査診断学（内視鏡・超音波）

2）川崎医科大学総合内科学 2

\section{Noriaki Manabe ${ }^{1)}$ and Ken Haruma ${ }^{2)}$}

1) Division of Endoscopy and Ultrasonography, Department of Clinical Pathology and Laboratory Medicine, Kawasaki Medical School, Japan.

2) Department of General Internal Medicine 2, Kawasaki Medical School, Japan.

\section{はじめに}

我が国では，昔から快適な日々を送るための 健康人の基本的条件として, 快食, 快眠ならび に快便の三原則が必須と言われている。しかし ながら，近年の食物繊維の摂取量の減少，スト レス社会の到来, 運動量の減少ならびに高齢化 等に伴い，便秘を訴える患者数が増加してい る。慢性便秘症は，心血管疾患のみならず，腎 疾患とも関連しており, 現在では, 消化器症状 の 1 つと捉えるより, 全身疾患の 1 つの症候と 捉えた方が適切と言われている。 また，これま での報告により, 慢性的な便秘症状は, 生活の 質や労働生産性に影響を及ぼすだけでなく, 患 者の生命予後にも関連することが明らかにされ ており (図) ${ }^{1)}$, 病態に沿った適切な治療が求め られている. しかしながら, 現状における慢性 便秘症患者の多くは, 市販薬を購入するか, あ るいは民間療法を用いて患者自身で対処してい ることが多く, 医療機関を受診し治療を受けて いる患者は 4 割に満たないことが明らかとなっ ている。ささらに, これまで慢性便秘症に対して よく処方されてきた薬劑の組み合わせとして, マグネシウムを含む塩類下剤と刺激性下剤が多 かったが，いずれも副作用の問題が注意喚起さ れており2), これまで当たり前に行っていた治 療法を考え直さなければならない時代に突入し てきていると言える。前述のように，まさに現 在, 我が国の慢性便秘症診療は変革期を迎えて いると考えられる.

このような背景のもと, 成人の慢性便秘症に 対する診療ガイドラインとして我が国で初めて 発刊された本ガイドラインは, 非常に臨床的意 義のあるものと考えられる. 本稿では, 本ガイ ドラインのなかで, 特に日常診療に関係する慢 性便秘症の定義・診断・治療を中心に解説する. 


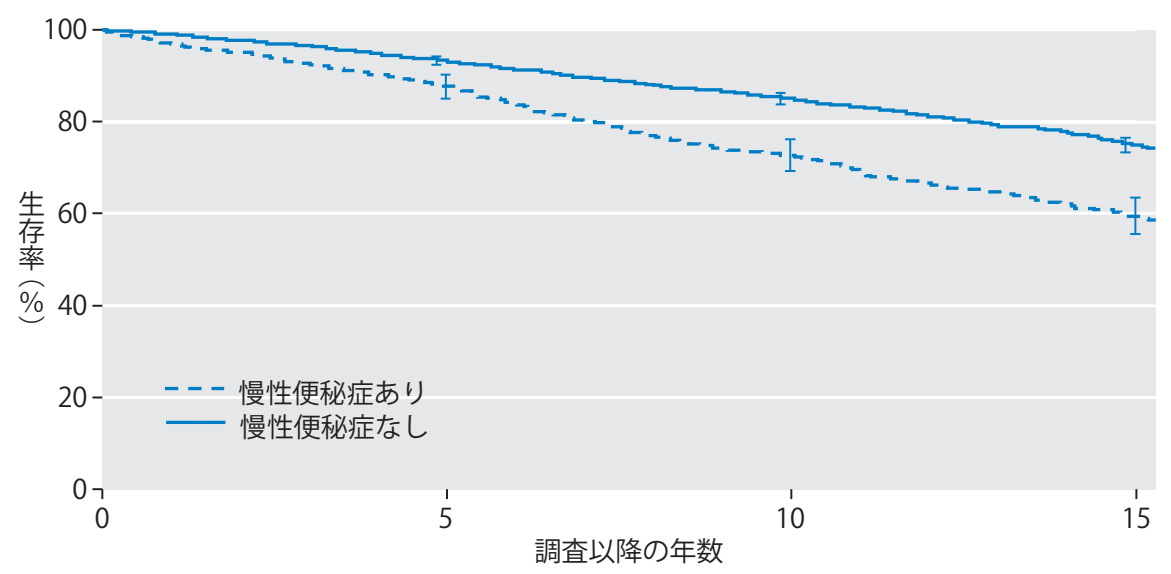

図 慢性便秘症状と生命予後の関係 (文献1より引用, 一部改変)

1988 1993 年に米国ミネソタ州の20歳以上の調査可能であった3,933例を対象とし， 2008 年までの生存状況を行政の死亡記録によって確認し，慢性便秘症状の有無で生存 率の差異を検討した。

\section{1. 慢性便秘症の定義}

便秘症に関連した症状には，単に排便回数の 減少だけでなく，硬便等の便性状の変化，いき みならびに残便感等の排便関連症状も含まれる 点が重要である.すなわち, 食事摂取量が少な い場合には, 排便回数が少ないからと言っても 必ずしも便秘とは言えず, また, 排便強迫神経 症等が背景疾患に存在する場合には, 残便感を 訴えても便そのものが直腸にない場合があり, 便秘とは言えない. 従って, 前述の理由から, 本ガイドラインでは, 便秘を「本来体外に排出 すべき翼便を十分量かつ快適に排出できない状 態」と定義している3).

便秘症は既に, これまでの疫学的データに基 づき策定された国際基準であるRome IV基準に 明確に定義されており4)(表1)，これに従って診 断していくのが望ましい. 本ガイドラインも, 診断基準としてRome IV基準を採用している. しかしながら日常診療では, 必ずしもこの診断 基準に沿って進めていく必要はなく,「本来体外 に排出すべき粪便を十分量かつ快適に排出でき ない状態」が持続し, 日常生活に支障が生じて
いれば便秘症と診断し, 治療を行ってよい点を 強調しておく.

\section{2. 慢性便秘症の診断 一二次性便秘の除外の重要性一}

慢性便秘症と診断した後にまず行わなければ ならない事項として, 二次性便秘症の除外が挙 げられる (表2 $)^{3)}$.まず, 大腸癌や腸閉塞に伴っ て生じる器質的疾患に伴う便秘の除外は必須で あり, 次に糖尿病, 甲状腺機能低下症やParkinson病に伴って生じる症候性便秘の除外も必須 である。さらに, 除外の必要な二次性便秘とし て, 特に高齢者医療においてしばしば問題とな るのが, 薬剤に伴って生じる便秘症である（表 $3)^{3)}$. 特に, 高齢者の便秘症状は老年症候群の 1つとしてみられることが多く, 薬剤性便秘の 可能性を念頭に置かない場合には見逃されてし まうケースがあり, 注意が必要である5).

\section{3. 慢性便秘症の病態分類}

慢性便秘症の原因から器質性を除いた機能性 


\section{表 1 慢性便秘症の診断基準（文献3より引用）}

1.「便秘症」の診断基準

以下の6項目のうち，2項目以上を満たす

a. 排便の 4 分の 1 超の頻度で，強くいきむ必要がある.

b. 排便の4分の 1 超の頻度で，鬼䔬状便または硬便（BSFSでタイプ1か2）である.

c. 排便の 4 分の 1 超の頻度で，残便感を感じる.

d. 排便の 4 分の 1 超の頻度で，直腸肛門の閉塞感や排便困難感がある.

e. 排便の 4 分の 1 超の頻度で，用手的な排便介助が必要である（摘便・会陰部圧迫など）。

f. 自発的な排便回数が，週に3回未満である.

2.「慢性」の診断基準

6力月以上前から症状があり，最近3カ月間は上記の基準を満たしていること.

BSFS : ブリストル便形状スケール

\section{表2 慢性便秘症を来たす基礎疾患}

\begin{tabular}{|c|c|}
\hline 内分泌・代謝疾患 & 糖尿病（自律神経障害を伴うもの），甲状腺機能低下症，慢性腎不全（尿毒症） \\
\hline 神経疾患 & $\begin{array}{l}\text { 脳血管疾患，多発性硬化症，Parkinson病，Hirschsprung病，脊髄損傷（あるいは脊䯣病変）， } \\
\text { 二分脊椎，精神発達遅滞 }\end{array}$ \\
\hline 膠原病 & 全身性硬化症（強皮症），皮膚筋炎 \\
\hline 変性疾患 & アミロイドーシス \\
\hline 精神疾患 & うつ病，心気症 \\
\hline 大腸の器質的異常 & 裂肛，痔核，炎 \\
\hline
\end{tabular}

疾患による慢性便秘症の分類を表43)に示す。一 般的に, 慢性便秘症は, 症状から排便回数減少 型・排便困難型に分けて考えると整理しやす く, それに対応した病態として, 大腸通過正常 型・大腸通過遅延型・便排出障害が関連付けら れる. 理想的には，この病態分類を念頭に置い て診断・治療を行うことが望ましいが，現状で 大腸通過時間検査や排便造影検査等が行えるの はごく一部の専門施設であり, 今後, 解決すべ き大きな課題と考える.

\section{4. 慢性便秘症の治療}

慢性便秘症の治療には保存的治療と外科的治 療が用いられる，保存的治療では，食習慣を含 む生活習慣の改善が行われ，奏効しない場合 に, 薬物治療や状況によっては摘便等の理学的 治療が開始される，現在までのところ, 食習慣 の改善を含めた生活習慣の改善による慢性便秘
症の症状改善効果に関するエビデンスレベルの 高い検討がなされていないのが現状であるが， 副作用の面, 安全性の面ならびに簡便さの観点 を考慮すると, 試行して問題となることはな く, 慢性便秘症治療の第一選択治療として問題 ないと考えられる。

現在, 薬物療法には数種類の異なった作用機 序の薬剤が用いられて扔り，それぞれに対する 推奨度とエビデンスの強さについては表 $5^{33} に$ 記載したと抢りである。欧米からは，既に慢性 便秘症に対する診断・治療ガイドラインが数編 報告されている6 8). 本邦のガイドラインの特 徵の 1 つとして, 漢方治療の項目が入っている 点が挙げられる. 本邦では, 以前より, 慢性便 秘症に対して漢方治療が経験的に用いられてき たが，エビデンスレベルの観点からは十分とは 言えず, 総合的に考えると, 推奨度の強さは 2 （“実施する”ことを提案する）となっている. な抢，慢性便秘症の治療に扔いて，推奨の強さ 
表3 慢性便秘症を起こす薬剤（文献3より引用）

\begin{tabular}{|c|c|c|}
\hline 薬剤種 & 薬品名 & 薬理作用，特性 \\
\hline 抗コリン薬 & $\begin{array}{l}\text { アトロピン，スコポラミン } \\
\text { 抗コリン作用をもつ薬剂 (抗うつ薬や一部の抗精神 } \\
\text { 病薬，抗Parkinson病薬，ベンゾジアゼピン，第一 } \\
\text { 世代の抗ヒスタミン薬など) }\end{array}$ & 消化管運動の緊張や蠕動運動, 腸液分泌の抑制作用 \\
\hline 向精神薬 & 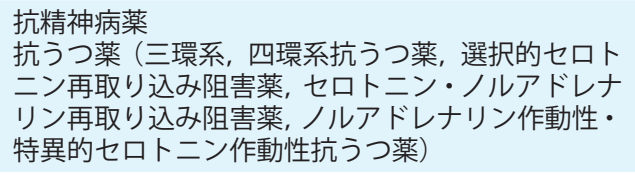 & $\begin{array}{l}\text { 抗コリン作用 } \\
\text { 四環系よりも環系抗うつ薬で便秘を引き起こし } \\
\text { やすい }\end{array}$ \\
\hline $\begin{array}{l}\text { 抗Parkinson } \\
\text { 病薬 }\end{array}$ & $\begin{array}{l}\text { ドパミン補充薬，ドパミン受容体作動薬 } \\
\text { 抗コリン薬 }\end{array}$ & $\begin{array}{l}\text { 中枢神経系のドパミン活性の増加や，ACh活性の低 } \\
\text { 下作用 } \\
\text { 抗コリン作用 }\end{array}$ \\
\hline オピオイド & モルヒネ, オキシコドン, コデイン, フェンタニル & $\begin{array}{l}\text { 消化管臓器からの消化酵素の分泌抑制作用 } \\
\text { 蠕動運動抑制作用 } \\
\text { セロトニンの遊離促進作用 }\end{array}$ \\
\hline 化学療法薬 & $\begin{array}{l}\text { 植物アルカロイド（ビンクリスチン，ビンデシン） } \\
\text { タキサン系（パクリタキセル） }\end{array}$ & $\begin{array}{l}\text { 末梢神経障害や自律神経障害 } \\
\text { 薬斉の影響とは異なり癌治療に伴う精神的ストレ } \\
\text { ス，摂取量の減少，運動量の低下なども関与 }\end{array}$ \\
\hline 循環器作用薬 & $\begin{array}{l}\text { カルシウム拮抗薬 } \\
\text { 抗不整脈薬 } \\
\text { 血管拡張薬 }\end{array}$ & $\begin{array}{l}\text { カルシウムの細胞内流入の抑制で腸管平滑筋が弛 } \\
\text { 緩する }\end{array}$ \\
\hline 利尿薬 & $\begin{array}{l}\text { 抗アルドステロン薬 } \\
\text { ループ利尿薬 }\end{array}$ & $\begin{array}{l}\text { 電解質異常に伴う腸管運動能の低下作用 } \\
\text { 体内の水分排出促進作用 }\end{array}$ \\
\hline 制酸薬 & $\begin{array}{l}\text { アルミニウム含有薬 (水酸化アルミニウムゲルやス } \\
\text { クラルファート) }\end{array}$ & 消化管運動抑制作用 \\
\hline 鉄剂 & フマル酸第一鉄 & 収斂作用で蠕動の抑制作用 \\
\hline $\begin{array}{l}\text { 吸着薬， } \\
\text { 陰イオン交換 } \\
\text { 樹脂 }\end{array}$ & $\begin{array}{l}\text { 沈降炭酸カルシウウム } \\
\text { セベラマー塩酸塩 } \\
\text { ポリスチンン酸カルシウム } \\
\text { ポリスチレンスルホン酸ナトリウム }\end{array}$ & $\begin{array}{l}\text { 排出遅延で薬剂が腸管内に蓄積し，二次的な蠕動運 } \\
\text { 動阻害作用 }\end{array}$ \\
\hline 制吐薬 & グラニセトロン, オンダンセトロン, ラモセトロン & 5-HT3 拮抗作用 \\
\hline 止痢薬 & ロペラミド & 末梢性オピオイド受容体刺激作用 \\
\hline
\end{tabular}

が 1（“実施する”ことを推奨する）の薬剤に は，浸透圧性下凨と上皮機能変容薬が挙げられ て抢り, その他の薬剤については, 推奨の強さ がそれぞれ2（“実施する”ことを提案する）と なっている，ここで注意が必要なのは, 推奨度 の強さは，その薬剤に関するエビデンスレベル と実臨床での有効性及び副作用の面を総合的に 考慮し, 作成委員全員でメール投票を行って $70 \%$ 以上の合意を持って最終決定したもので あり, 推奨度の強さが必ずしも薬効の強さを示 すものではない点に留意していただきたい。ま た, ガイドライン作成時には新規便秘薬が出
揃っていなかった背景があり, 敢えて今回のガ イドラインには治療アルゴリズムが作成されて いない点も勘案いただきたい. 従って, 次回の 慢性便秘症診療ガイドライン改訂時には治療ア ルゴリズムが作成されることと思われる.

保存的治療では病状の改善を認めず，便秘の 病態評価により適応がある場合には, 表63)に示 すような外科的治療が行われることになってい る.しかしながら，いずれの外科的治療を行う にしても病態評価が重要であり, 前述したよう に, 現時点において十分な病態評価が行える施 設は限られているのが現状である. 慢性便秘症 
表4 慢性便秘 (症) の分類（文献3より）

\begin{tabular}{|c|c|c|c|c|}
\hline 原因分類 & 症状分類 & $\begin{array}{l}\text { 分類・診断のため } \\
\text { の検査方法 }\end{array}$ & $\begin{array}{l}\text { 専門的検査に } \\
\text { よる病態分類 }\end{array}$ & 原因となる病態・疾患 \\
\hline \multirow{4}{*}{ 機能性 } & \multirow[t]{2}{*}{$\begin{array}{l}\text { 排便回数 } \\
\text { 減少型 }\end{array}$} & \multirow[t]{2}{*}{$\begin{array}{l}\text { 大腸通過時間検査 } \\
\text { など }\end{array}$} & 大腸通過遅延型 & $\begin{array}{l}\text { 特発性 } \\
\text { 症候性 : 代謝・内分泌疾患, 神経・筋疾患, 膠原病, } \\
\text { 便秘型過敏性腸症候群など } \\
\text { 薬剂性 : 向精神薬，抗コリン薬，オピオイド系薬など }\end{array}$ \\
\hline & & & \multirow{2}{*}{ 大腸通過正常型 } & $\begin{array}{l}\text { 経口摂取不足（食物繊維摂取不足を含む） } \\
\text { 大腸通過時間検査での偽陰性 など }\end{array}$ \\
\hline & \multirow[b]{2}{*}{$\begin{array}{l}\text { 排便 } \\
\text { 困難型 }\end{array}$} & $\begin{array}{l}\text { 大腸通過時間検査, } \\
\text { 排便造影検査など }\end{array}$ & & $\begin{array}{l}\text { 硬便による排便困難・残便感 } \\
\text { (便秘型過敏性腸症候群など) }\end{array}$ \\
\hline & & 排便造影検査など & 機能性便排出障害 & $\begin{array}{l}\text { 骨盤底筋協調運動障害 } \\
\text { 腹圧 (怒責力) 低下 } \\
\text { 直腸感覚低下 } \\
\text { 直腸収縮力低下 など }\end{array}$ \\
\hline
\end{tabular}

表 5 慢性便秘症の治療（その1）（文献3より）

\begin{tabular}{|c|c|c|c|}
\hline $\mathrm{CQ}$ & ステートメント & \begin{tabular}{c|} 
推奨の \\
強さ
\end{tabular} & $\begin{array}{l}\text { エビデンス } \\
\text { レベル }\end{array}$ \\
\hline $\begin{array}{l}\text { CQ5-01 } \\
\text { 慢性便秘症に生活習慣の改善は有効か? }\end{array}$ & $\begin{array}{l}\text { 適切な食事や運動，腹壁マッサージは慢性便秘症の症 } \\
\text { 状改善に有効であり行うことを提案する. }\end{array}$ & 2 & C \\
\hline $\begin{array}{l}\text { CQ5-02 } \\
\text { 慢性便秘症にプロバイオティクスは有効か? }\end{array}$ & $\begin{array}{l}\text { 慢性便秘患者においてプロバイオティクスは排便回数の } \\
\text { 増加に有効であり，治療法として用いることを提案する. }\end{array}$ & 2 & B \\
\hline $\begin{array}{l}\text { CQ5-03 } \\
\text { 慢性便秘症に膨張性下剂は有効か? }\end{array}$ & $\begin{array}{l}\text { 便秘型過敏性腸症候群に膨張性下剂を使用することを } \\
\text { 提案する. }\end{array}$ & 2 & C \\
\hline $\begin{array}{l}\text { CQ5-04 } \\
\text { 慢性便秘症に浸透圧性下剂は有効か? }\end{array}$ & $\begin{array}{l}\text { 慢性便秘症に対して浸透圧性下剂は有用であり使用す } \\
\text { ることを推奨する.ただし，ママグネシウを含む塩類下 } \\
\text { 剂使用時は，定期的なマグネシウム測定を推奨する. }\end{array}$ & 1 & $A$ \\
\hline $\begin{array}{l}\text { CQ5-05 } \\
\text { 慢性便秘症に刺激性下剂は有効か? }\end{array}$ & $\begin{array}{l}\text { 慢性便秘症に対して，刺激性下剂は有効であり，頓用ま } \\
\text { たは短期間の投与を提案する. }\end{array}$ & 2 & B \\
\hline $\begin{array}{l}\mathrm{CQ} 5-06 \\
\text { 慢性便秘症に上皮機能変容薬は有効か？ }\end{array}$ & $\begin{array}{l}\text { 慢性便秘症に対して上皮機能変容薬は有用であり，使用 } \\
\text { することを推奨する. ただし，ルビプロストンは妊婦に } \\
\text { は投与禁忌であり，若年女性に生じやすい悪心の副作用 } \\
\text { にも十分に注意する必要がある. }\end{array}$ & 1 & $A$ \\
\hline $\begin{array}{l}\text { CQ5-07 } \\
\text { 慢性便秘症に消化管運動賦活薬は有効か? }\end{array}$ & $\begin{array}{l}\text { 慢性便秘症に消化管運動賦活薬は有効であるが, 日本 } \\
\text { で使用可能な薬剤のエビデンスは少ない. 慢性便秘症に } \\
\text { 消化管運動賦活薬を用いることを提案する. }\end{array}$ & 2 & A \\
\hline $\begin{array}{l}\text { CQ5-08 } \\
\text { 慢性便秘症に漢方薬は有効か? }\end{array}$ & $\begin{array}{l}\text { 慢性便秘症の治療薬として一部の漢方薬は有効であり, } \\
\text { 使用することを提案する. }\end{array}$ & 2 & $C$ \\
\hline $\begin{array}{l}\text { CQ5-09 } \\
\text { 慢性便秘症に浣腸，坐剂，摘便，逆行性洗 } \\
\text { 腸法は有効か? }\end{array}$ & $\begin{array}{l}\text { 慢性便秘症の治療として浣腸，坐剂，摘便，逆行性洗 } \\
\text { 腸法は有効であり，使用することを提案する. }\end{array}$ & 2 & $C$ \\
\hline
\end{tabular}

が今後増加していくことが疑いのないことを考 慮すると, 病態評価を行える施設を整備してい くことは非常に重要なことと考える.

\section{おわりに}

今後，ますます高齢化が進む社会において， 慢性便秘症治療の需要は必然的に高まっていく ものと考えられる．慢性便秘症は生命予後にも 
表6 慢性便秘症の治療（その2）(文献3より)

\begin{tabular}{|c|c|c|c|}
\hline $\mathrm{CQ}$ & ステートメント & \begin{tabular}{l|} 
推奨の \\
強さ
\end{tabular} & $\begin{array}{l}\text { エビデンス } \\
\text { レベル }\end{array}$ \\
\hline $\begin{array}{l}\mathrm{CQ} 5-10 \\
\text { 慢性便秘症にバイオフィードバック療法は } \\
\text { 有効か? }\end{array}$ & $\begin{array}{l}\text { 機能性便排出障害による慢性便秘症に対して，バイオ } \\
\text { フィードバック療法は有用であり，施行することを提案する. }\end{array}$ & 2 & A \\
\hline $\begin{array}{l}\text { CQ5-11 } \\
\text { 慢性便秘症に精神・心理療法は有効か? }\end{array}$ & $\begin{array}{l}\text { 慢性便秘症に対する精神・心理療法は有効である可能性 } \\
\text { があり，行うことを提案する. }\end{array}$ & 2 & C \\
\hline $\begin{array}{l}\text { CQ5-12 } \\
\text { 慢性便秘症に順行性洗腸法 (antegrade } \\
\text { continence enema:ACE) は有効か? }\end{array}$ & $\begin{array}{l}\text { 順行性洗腸法は，保存的療法が無効か継続困難な高度の } \\
\text { 便秘症に対して，人工肛門や大腸切除などの手術を回避す } \\
\text { るための外科的治療法として有用であり，施行することを } \\
\text { 提案する. }\end{array}$ & 2 & C \\
\hline $\begin{array}{l}\text { CQ5-13 } \\
\text { 大腸通過遅延型便秘に大腸切除術は有効 } \\
\text { か? }\end{array}$ & $\begin{array}{l}\text { 大腸通過遅延型便秘に対する結腸全摘＋回腸直腸吻合 } \\
\text { は,一定の基準のもとに患者を選択すれば有効であり，行 } \\
\text { うことを提案する. }\end{array}$ & 2 & C \\
\hline $\begin{array}{l}\text { CQ5-14 } \\
\text { 便排出障害に外科的治療は有効か? }\end{array}$ & $\begin{array}{l}\text { 便秘症の原因が直腸脱，直腸瘤，直腸重積などである場 } \\
\text { 合は外科的治療が有効であり，行うことを提案する. }\end{array}$ & 2 & B \\
\hline
\end{tabular}

関連しており, 病態に沿った適切な治療が必要 である、しかしながら，現状では，治療方針決 定に直結する排便造影検査や大腸通過時間検査 等の各種病態機能評価が十分に行える施設が限 られているのが問題点として挙げられる. また 近年, 数々の新規作用薬が処方可能になってお り, 以前と比較して, 本邦の便秘治療薬の選択 肢は格段に広がったと言える。これに伴い，今
後は, 各便秘治療薬の位置付けとその使い分け を明らかにしていくことが重要であり, それに 向けたエビデンスの構築が急務と思われる.

著者のCOI (conflicts of interest) 開示：眞部紀明；講演 料 (アステラス製薬，マイランEPD)，春間 賢；講演料 (アステラス製薬)

\section{文献}

1) Chang JY, et al : Impact of functional gastrointestinal disorders on survival in the community. Am J Gastroenterol $105: 822-832,2010$.

2）医薬品・医療機器等安全性情報 No.328. 2015年 12月. https://www.pmda.go.jp/files/000208517.pdf

3）日本消化器病学会関連研究会 慢性便秘の診断・治療研究会編：慢性便秘症診療ガイドライン2017. 南江堂, 東京, 2017.

4) Lacy BE, et al : Bowel disorders. Gastroenterology $150: 1393-1407,2016$.

5）厚生労働省：高齢者の医薬品適正使用の指針（総論編）について. 平成30年 5 月 29 日. 医政安発 0529 第 1 号・薬 生安発0529第 1 号.

6) Serra J, et al : Clinical practice guidelines for the management of constipation in adults. part 2 : diagnosis and treatment. Gastroenterol Hepatol 40 : 303-316, 2017.

7) Wald A : Constipation : advances in diagnosis and treatment. JAMA 315 : 185-191, 2016.

8) Tack J, et al : Diagnosis and treatment of chronic constipation--a European perspective. Neurogastroenterol Motil $23: 697-710,2011$. 